\title{
Potential of underutilized wild crops in Koraput, Odisha, India for improving nutritional security and promoting climate resilience
}

\author{
Debabrata Panda* and Sharat Kumar Palita
}

Indigenous and wild crop resources play a significant role in food and nutrition security, and are also important resources for sustainable food systems under climate change. Koraput district, Odisha is one of the agro-biodiversity hotspots in India dominated by tribal communities. The plant genetic resources of this region are of significance not only for the diversity, but also their consumption pattern. The present study aimed to chronicle the nutritional value of selected neglected and underutilized crop species of Koraput. Although these plant species are useful for poor and marginalized farmers, they are largely ignored by the scientific community, breeders and policymakers. Therefore, this study highlights the nutritional and climate-resilient traits of such species for conservation and further utilization. Mass consumption, commercialization and bio-prospecting of these valuable resources would be the right step for ensuring food and nutritional security in future climate change scenarios.

Keywords: Climate resilience, indigenous landrace, nutritional security, wild crops.

Climate change impends to intensify prevailing threats to food and livelihood security and is expected to affect all components of food security such as access, availability and utilization ${ }^{1}$. In general, food availability has been affected by changes in arable land as well as variations in agricultural yields ${ }^{2}$. The transition in global food and nutrition has taken many different interventions for feeding the anticipated 9 billion population in 2050, healthily, equitably and sustainably ${ }^{3}$. Further, majority of the people in different countries, including India are suffering from inequality in nutrition and various micronutrient deficiencies ${ }^{4}$. Therefore, in many countries of the world food and nutritional security has become a major concern under climate change 5 . In spite of efforts being taken to increase the productivity of some domesticated crops, nutritional security and climate remain global concerns ${ }^{6}$. The number of undernourished people has increased to about 821 million globally and feeding them depends not only on improving productivity of domesticated crops but also on the use of indigenous crop species ${ }^{7}$. In India, around 1.38 billion people will undergo changes in their food quality as well as quantity by 2021 . The transforma-

Debabrata Panda and Sharat Kumar Palita are in the Department of Biodiversity and Conservation of Natural Resources, Central University of Odisha, Koraput 764 021, India.

*For correspondence. (e-mail: dpanda80@gmail.com) tions in the agri-food system and Westernization of diets are the key concerns of food habit in India ${ }^{8}$. Thus, neglected and underutilized but nutrient-rich plant species could help bring transformation in food systems and improve health and nutritional security.

Globally, climate change is expected to exacerbate various abiotic and biotic stresses ${ }^{9}$. The new challenge of climate change will require resilience of crop-production systems by tolerance to individual and multiple stresses ${ }^{10}$. Further to maintain yield stability and increase the yield, an increase in leaf photosynthesis efficiency is required in the changing climate ${ }^{11}$. Identification and improvement of native or traditional crops that are adaptive to local climate is one solution that can effectively resist biotic and/or abiotic stresses ${ }^{12}$. Several researchers advocated that locally available underutilized crop resources might possess high genetic variation and are important for climate resilience ${ }^{6,13,14}$. Underutilized indigenous crops are those which have originated in a specific geographic location and have undergone wide domestication leading to local varieties ${ }^{14,15}$. Although wild and underutilized plants have not received enough attention in food security, various researchers have recommended their use in sustainable agriculture ${ }^{6,14,16}$. For integrating them into developmental interventions, region-specific assessment of these neglected and underutilized species is neces$\operatorname{sary}^{17}$. 
Koraput is a tribal-dominated district of Odisha and a hotspot of agro-biodiversity in the Eastern Ghats of India $^{18}$. In the global context, the plant genetic repository of this region assumes greater significance and Koraput is considered as a centre of diversity for many food crops, including rice ${ }^{19}$. Recently, Koraput has been declared by the Food and Agriculture Organization (FAO), Rome, as a global agricultural heritage site $^{13}$. Since historical times, plants were collected from the forest, for food and medicine by tribal people who developed various processing methods according to their needs. With the onset of settled agriculture and modernization, this knowledge is being lost at a rapid pace, which may lead to reduced diversity of indigenous crops in this region ${ }^{20}$. Therefore, the focus of this study is to highlight the nutritional value of selected neglected and underutilized crop resources such as indigenous rice, millets, wild fruits and leaves and yam of Koraput for conservation and further utilization. It also indicates the importance of these indigenous species for food and nutritional security along with their climateresilient characteristics.

\section{Methodology}

A mixed method of review approach was employed, comprising different research outcomes of the neglected and underutilized crop species used by different tribal people in Koraput. Information on underutilized crop resources was collected from several tribal communities of Koraput district. The data on consumption pattern and nutritional importance were collected through questionnaire, personal interviews with traditional healers and the published literature. This study on the nutritional and climate-resilient traits of indigenous rice, millets and wild yam is based on the synthesis of experiments carried out in our laboratory at the Central University of Odisha, Koraput or elsewhere.

\section{Physiographic importance of the study site}

Koraput is a tribal-dominated district of Odisha $\left(18^{\circ} 14^{\prime}-\right.$ $19^{\circ} 14^{\prime} \mathrm{N}$ lat. and $82^{\circ} 05^{\prime}-83^{\circ} 25^{\prime} \mathrm{E}$ long.; Figure 1$)$. This region is unique due to its topographic and ecological diversity with great variation in altitude (100$1672 \mathrm{~m} \mathrm{amsl}$ ). The district is predominantly inhabited by most of the primitive tribes, viz. Paroja, Bhumia, Gadaba, Bhatra, Durua and Kandha constituting about $50.6 \%$ of the total population ${ }^{13}$. Also, $72-83 \%$ of the people of this region live below the poverty line compared to $47 \%$ for Odisha and $26 \%$ for India ${ }^{12}$. Rainfall and temperature vary from 1320 to $1520 \mathrm{~mm}$ and $13.5^{\circ} \mathrm{C}$ to $40^{\circ} \mathrm{C}$ respectively, annually. This region comes under three agroclimatic zones: the Eastern Ghats highland zone, Western undulating zone and South Eastern Ghats zone ${ }^{21}$.

\section{Underutilized crop species for food and nutritional security}

The plant genetic resources of Koraput are significant in the global context. There are nearly 79 angiosperms and one gymnosperm plant species endemic to the region ${ }^{22,23}$. The Swaminathan Research Foundation, Jeypore, Odisha has been taking a leading role in this region for enabling tribal and rural families to derive economic benefits from genetic resources. They have recorded 340 local varieties of rice, eight different species of minor millets, seven pulses species, five species of oilseeds and seven vegetable species in this region ${ }^{22}$. Table 1 shows some of the underutilized and wild crop species of Koraput with their nutritional importance.

\section{Indigenous rice diversity of Koraput}

Koraput region is famous for traditional rice landraces and is recognized as one of the centres of origin of Asian cultivated rice ${ }^{24}$. These local rice varieties show many primitive characteristics and have been traditionally cultivated by farmers using their traditional knowledge $\mathrm{e}^{25-27}$. The diversity and genetic variation of rice germplasms in this region have been recorded by several researchers ${ }^{24,25,28}$. During 1955-1959, a total of 1745 germplasms of cultivated rice were collected by the ICAR-Central Rice Research Institute (CRRI), Cuttack, Odisha. After 40 years in 1995-1996 National Bureau of Plant Genetic Resources (NBPGR), New Delhi explored this region and collected 318 accessions $^{25}$. Now-a-days due to modern agricultural practices and competition with high-yielding varieties, these vital genetic resources are being gradually eroded ${ }^{28}$. In spite of being less productive, traditional rice landraces ensure food and livelihood security of the tribal people due to several nutritional and agronomic traits ${ }^{29}$. Mishra and Chaudhury ${ }^{19}$ reported that some of the indigenous

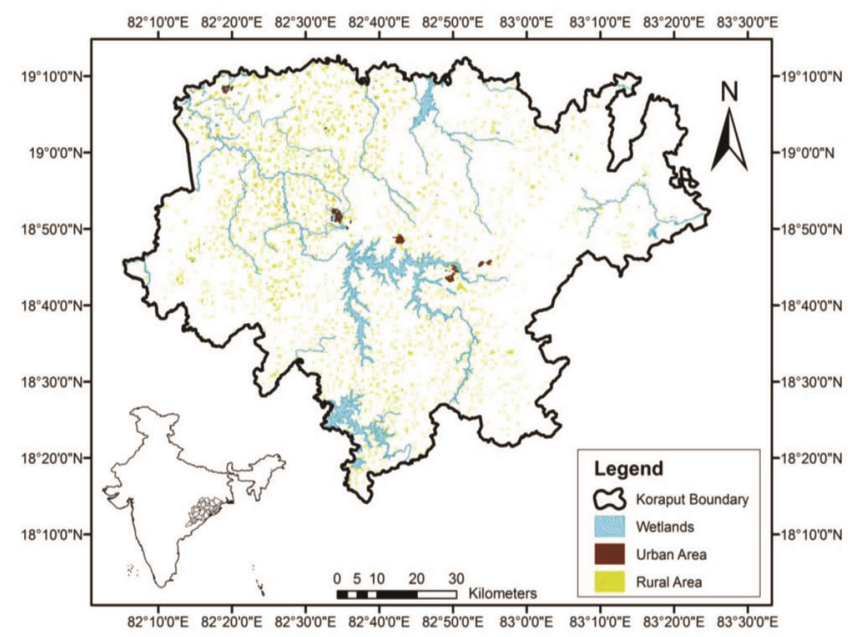

Figure 1. Map showing the study site Koraput district, Odisha, India. 
GENERAL ARTICLES

Table 1. List of underutilized and wild crop species of Koraput for nutritional benefits

\begin{tabular}{|c|c|c|c|}
\hline Crops & Underutilized species & Nutritional quality & Reference \\
\hline \multirow[t]{3}{*}{ Rice landraces } & $\begin{array}{l}\text { Machakanta, Haladichudi, Para Dhan, Muktabali, } \\
\text { Sapuri Umuriachudi }\end{array}$ & $\begin{array}{l}\text { Popular nutritious, non-sticky cooked rice, } \\
\text { slender grain best for pulao and biryani }\end{array}$ & 19,26 \\
\hline & $\begin{array}{l}\text { Kalajeera, Gangabali, Kuyerkuling, Deulabhoga, } \\
\text { Lactimachi, Sapuri, Dudhamani, Muktabali } \\
\text { and Nadiarasa }\end{array}$ & Popular aromatic and scented rice landraces & 26,27 \\
\hline & $\begin{array}{l}\text { Bhatamalli, Kandulakath, Haladiganthi, Kalachudi } \\
\text { Mallimakada, maligoindi, Beda Gurumukhi }\end{array}$ & $\begin{array}{l}\text { Popular pigmented and medicinal rice } \\
\text { landraces }\end{array}$ & 31 \\
\hline Millets & $\begin{array}{l}\text { Finger millet, foxtail millet, kodo millet, proso } \\
\text { millet, little millet and sorghum millet }\end{array}$ & $\begin{array}{l}\text { Superior nutritional, mineral and vitamin } \\
\text { composition; higher physico-functional } \\
\text { parameters }\end{array}$ & $13,19,33$ \\
\hline Wild edible tubers & $\begin{array}{l}\text { Dioscorea oppositfolia, D. hispida, D. hamiltoni, } \\
\text { D. bulbifera, D. pubra, D. pentaphyla, } \\
\text { D. wallichi and D. glabra }\end{array}$ & $\begin{array}{l}\text { Superior nutritional, mineral and antioxidant } \\
\text { contents }\end{array}$ & 35,36 \\
\hline Wild edible leaves & $\begin{array}{l}\text { Butea monosperma, Bauhinia purpurea, Paederia } \\
\text { foetida, Andrographis paniculata, Sterculia } \\
\text { foetida, Cassioides, Meyma spinosa }\end{array}$ & Better nutritional and health benefits & $19,23,34$ \\
\hline Wild edible fruits & $\begin{array}{l}\text { Buchanania lanzan, Carissa opaca, Careya } \\
\text { arborea, Diospyros melanoxylon, Syzygium } \\
\text { cumini, Mangifera indica, Artocarpus } \\
\text { heterophyllus, Phoenix sylvestris, } \\
\text { Schleichera oleosa, Madhuca indica }\end{array}$ & Better nutritional and health benefits & 19,23 \\
\hline Wild flowers & $\begin{array}{l}\text { Indigofera pulchella, Cordia oblique, Sesbania } \\
\text { grandiflora, Woodfordia fruticose, Tamarindus } \\
\text { indica, Madhuca indica and Azadirachta indica }\end{array}$ & Good nutritional and health benefits & 23 \\
\hline
\end{tabular}

rice landraces such as Machhakanta, Haladichudi, Paradhan, Muktabali, Sapuri and Umuriachudi hold superior grain quality along with cooking and nutritional quality (Table 1). Arunachalam et al. ${ }^{26}$ and Roy et al. ${ }^{27}$ studied different aromatic rice landraces such as Kalajeera, Gangabali, Kuyerkuling, Deulabhoga, Lactimachi, Sapuri, Dudhamani, Muktabali and Nadiarasa of this region and claimed that they have superior aroma along with grain quality traits. Genetic variation of seed quality traits was observed among these genotypes; notably the 'Sapuri' variety showed highest seed length and width ratio (3.57 \pm 0.06$)$ with best quality seeds of this locality. The varieties 'Muktabali' and 'Kuyerkuling' showed the highest protein content $(4.50 \pm 0.03 \mathrm{mg} / \mathrm{g})$ and 'Dudhamani' variety showed the highest starch content $(803 \pm 20 \mathrm{mg} / \mathrm{g})$ among traditional varieties compared to the modern aromatic variety 'Sugandha' $(\mathrm{CR} 907)^{30}$. Edwina et $a l^{31}$ studied the biochemical and antioxidant activities of several popular pigmented rice landraces such as Bhatamalli, Kandulakath, Haladiganthi, Kalachudi, Mallimakada, Maligoindi, Beda Gurumukhi of Koraput. The amylose, total anthocyanin and phytate contents of these landraces ranged from $22.01 \%$ to $44.38 \%, 28.73$ to $193.36 \mathrm{mg} / 100 \mathrm{~g}$ and 1.16 to $24.49 \mathrm{mg} / 100 \mathrm{~g}$ respectively. Phenol, polyphenol and antioxidant capacity varied from 233.92 to $251.38 \mathrm{mg} / 100 \mathrm{~g}, 252.43$ to $284.36 \mathrm{mg} /$ $100 \mathrm{~g}$ and $19.37 \%$ to $38.10 \%$ respectively. Maganti et $a{ }^{32}$ reported variation of iron and zinc contents among traditional rice genotypes of this region. They found that landraces such as Raskadam, Machhakanta and Haldichudi contain greater than $15.1 \mathrm{mg} / \mathrm{kg}$ of iron and $25.1 \mathrm{mg} / \mathrm{kg}$ of zinc along with higher accumulation of micronutrients. Some of the local rice landraces also exhibited higher content of calcium, iron and $\mathrm{zinc}^{31}$. The highest calcium $(635 \mathrm{mg} / 100 \mathrm{~g})$ and zinc $(8.67 \mathrm{mg} / 100 \mathrm{~g})$ contents were found in Paradhan and iron $(38.5 \mathrm{mg} / 100 \mathrm{~g}$ ) in Malligoindi variety. These landraces can provide nutritive and health benefits for rice-based diets.

\section{Indigenous millet diversity of Koraput}

Koraput is also famous for minor millets which are conventionally grown and consumed by tribal farmers. In Koraput, finger millet is cultivated in about $16 \%$ of the total gross cropping area ${ }^{12}$. Different millet species are cultivated by tribal communities having varied duration of maturity and grains with variation in shape, size and colour under multiple cropping systems ${ }^{19}$. They have been cultivating indigenous millet varieties, importantly Eleusine coracana (L.) Gaertn., Panicum sumatrense Roth. ex Roem. et Schult. and Setaria italica (L.) P. Beauv. The tribal people frequently use different millets and employ various processing methods in accordance to their needs and traditional use ${ }^{19}$. Panda et al. ${ }^{33}$ studied the bioavailability of nutrients in different indigenous millets of Koraput to promote their utilization and bioprospecting. The proximate composition such as ash, crude fibre and crude fat of millet flours varied from $1.4 \%$ to $4.0 \%$, 
Table 2. Nutritional superiority of wild yam species of Koraput over cultivated species (Dioscorea alata) ${ }^{35,36}$

\begin{tabular}{|c|c|c|c|c|c|}
\hline Parameter & Dioscorea oppositifolia & Dioscorea hamiltonii & Dioscorea pubera & Dioscorea wallichii & Dioscorea alata \\
\hline Ash content ( $\%)$ & $4.39 \pm 0.33$ & $5.42 \pm 0.43$ & $4.24 \pm 0.48$ & $3.82 \pm 0.24$ & $3.16 \pm 0.21$ \\
\hline Crude fat $(\%)$ & $1.62 \pm 0.03$ & $1.90 \pm 0.08$ & $1.55 \pm 0.03$ & $0.91 \pm 0.16$ & $0.91 \pm 0.02$ \\
\hline Crude fibre $(\%)$ & $1.52 \pm 0.01$ & $1.45 \pm 0.06$ & $1.60 \pm 0.12$ & $2.02 \pm 0.01$ & $1.40 \pm 0.02$ \\
\hline Carbohydrate (\%) & $25.30 \pm 0.41$ & $22.97 \pm 0.35$ & $26.66 \pm 0.89$ & $21.87 \pm 0.52$ & $24.07 \pm 0.70$ \\
\hline Crude protein (\%) & $9.50 \pm 0.23$ & $9.77 \pm 0.11$ & $10.28 \pm 0.10$ & $8.38 \pm 0.25$ & $8.78 \pm 0.13$ \\
\hline Gross energy (kcal) & $153 \pm 1$ & $148 \pm 2$ & $161 \pm 2$ & $129 \pm 2$ & $139 \pm 2$ \\
\hline Vitamin-C (mg/100 g) & $5.67 \pm 0.01$ & $5.66 \pm 0.17$ & $9.42 \pm 0.23$ & $5.36 \pm 0.34$ & $5.01 \pm 0.24$ \\
\hline Vitamin-E (mg/100g) & $0.55 \pm 0.06$ & $0.66 \pm 0.03$ & $0.57 \pm 0.01$ & $0.40 \pm 0.04$ & $0.36 \pm 0.03$ \\
\hline Diosgenin (mg/100 g) & $4.15 \pm 0.10$ & $4.85 \pm 0.21$ & $6.66 \pm 0.04$ & $4.89 \pm 0.15$ & $3.75 \pm 0.07$ \\
\hline Phytate $(\mathrm{mg} / 100 \mathrm{~g})$ & $4.60 \pm 0.30$ & $4.49 \pm 0.27$ & $4.27 \pm 0.08$ & $4.47 \pm 0.35$ & $3.21 \pm 0.04$ \\
\hline Oxalate (mg/100 g) & $0.172 \pm 0.008$ & $0.159 \pm 0.007$ & $0.150 \pm 0.003$ & $0.156 \pm 0.002$ & $0.138 \pm 0.008$ \\
\hline Sodium (mg/100 g) & $60.33 \pm 1.87$ & $89.42 \pm 0.98$ & $67.24 \pm 1.85$ & $68.41 \pm 1.89$ & $55.06 \pm 1.16$ \\
\hline Potassium (mg/100 g) & $1248 \pm 4$ & $1029 \pm 6$ & $1140 \pm 4$ & $1161 \pm 4$ & $989 \pm 5$ \\
\hline Iron $(\mathrm{mg} / 100 \mathrm{~g})$ & $26.61 \pm 0.27$ & $28.61 \pm 0.85$ & $24.18 \pm 0.62$ & $17.09 \pm 0.57$ & $19.75 \pm 0.24$ \\
\hline Calcium (mg/100 g) & $52.32 \pm 0.33$ & $46.17 \pm 0.20$ & $74.79 \pm 0.40$ & $69.28 \pm 0.31$ & $43.13 \pm 0.16$ \\
\hline Zinc $(\mathrm{mg} / 100 \mathrm{~g})$ & $4.70 \pm 0.27$ & $3.60 \pm 0.31$ & $6.21 \pm 0.18$ & $5.45 \pm 0.33$ & $3.43 \pm 0.21$ \\
\hline Phosphorus (mg/100 g) & $235.37 \pm 2.01$ & $214.63 \pm 1.85$ & $248.27 \pm 2.00$ & $213.93 \pm 2.35$ & $218.20 \pm 1.64$ \\
\hline
\end{tabular}

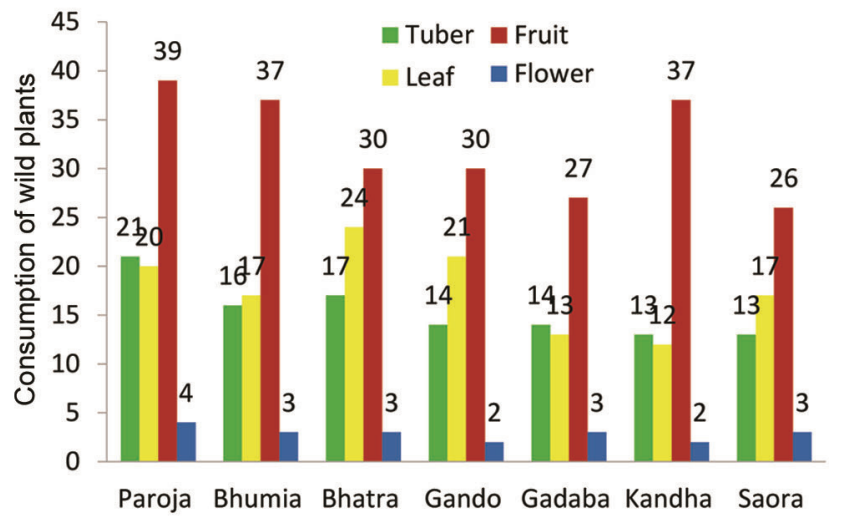

Tribal communities

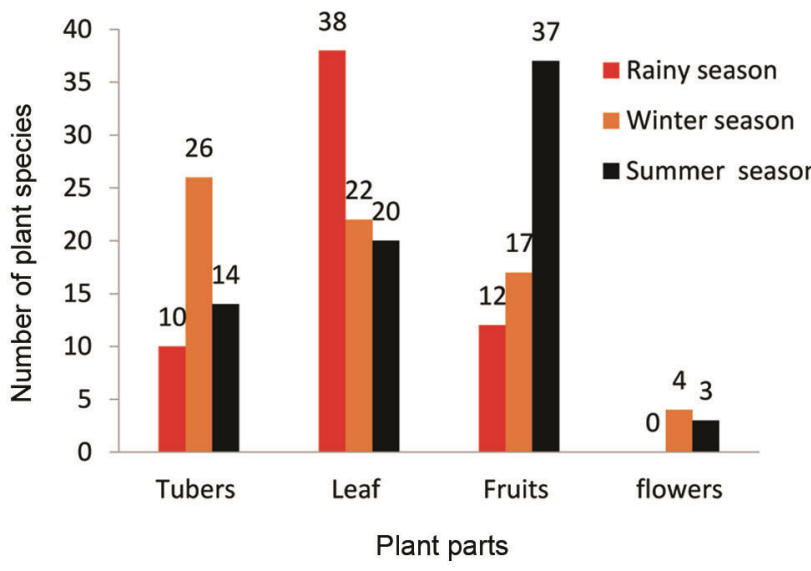

Figure 2. Tribal-specific consumption patterns and seasonal availability of wild edible plants in Koraput ${ }^{23}$.

$2.0 \%$ to $11.0 \%$ and $1.1 \%$ to $3.6 \%$ respectively. The nutritional parameters significantly varied among the genotypes: sugar (8.3-25.4\%), starch (51.6-69.1\%), amylose $(5.2-12.5 \%)$ and protein $(9.3 \%-14.3 \%)$. Potassium and sodium contents ranged from 227.4 to $441.2 \mathrm{mg}$ and 10.30 to $11.05 \mathrm{mg}$ per $100 \mathrm{~g}$ dry wt respectively ${ }^{33}$. Some traditional millets are having lower levels of sodium compared to potassium, which suggests that these are advantageous for health.

\section{Wild edible plant diversity of Koraput}

Padhan and Panda ${ }^{23}$ documented the usage of 156 wild plant species by tribal people of Koraput for food and medicine. Figure 2 presents the tribal-specific consumption patterns of different wild plant species. The wild species most consumed by the tribals are wild fruits (39) followed by leafy vegetables (24), tubers (21) and flowers (4). Paroja tribe uses more wild resources compared to the other tribes. They collect mainly wild tubers in winter season and green leaves in the rainy season. Wild fruits and flowers are mainly collected during winter and summer seasons. Mishra and Chaudhury ${ }^{19}$, and Mahapatra and Panda ${ }^{16}$ reported different wild fruits and berries having a significant role in the food habit of tribal people of Koraput (Table 1). Usually oil is extracted from the seeds of Madhuca indica, Azadirachta indica and Schleichera oleosa and commercialized. More importantly, these species need to be promoted as a natural source of antioxidants and nutraceuticals. Different tribal groups also used various leafy vegetables (Table 1). Different leafy vegetables are widely distributed in the rainy season in open fields or agricultural fields. Misra ${ }^{34}$ highlighted the nutritional and antioxidant properties of wild leafy plants and their potential for better health and nutrition. The leafy vegetable Moringa oleifera (6.6\%) showed highest crude protein and highest total lipid $(0.013 \mathrm{mg} / \mathrm{g})$ content, whereas vitamin B1 was superior in Glinus oppositifolius $(0.0015 \mathrm{mg} / \mathrm{g})$. Table 1 also shows the list of flowers used by various tribes and their consumption patterns. Wild yam species are popular and used as food by the tribals of Koraput. These include Dioscorea bulbifera L., D. glabra Roxb., D. hamiltonii Hook.f., D. hispida 
GENERAL ARTICLES

Table 3. List of underutilized and wild crop species of Koraput for climate resilience

\begin{tabular}{|c|c|c|c|}
\hline Crop & Underutilized species & Climate-resilient traits & Reference \\
\hline \multirow[t]{5}{*}{ Rice landraces } & $\begin{array}{l}\text { Machhakanta, Kalajeera, Pandakagura, } \\
\text { Mugudi, Haladichudi and Dangarbayagundar }\end{array}$ & High level of tolerance to drought stress & $29,39,41$ \\
\hline & $\begin{array}{l}\text { Samudrabali, Basnamundi, Gadaba, Surudaka } \\
\text { and Dokarakuji }\end{array}$ & $\begin{array}{l}\text { High level of tolerance to flash flood and stagnant } \\
\text { flooding; better survival than check variety } \\
\text { FR13A during flooding }\end{array}$ & 42,44 \\
\hline & Bausaganthi, Patadhan and Basantichudi & $\begin{array}{l}\text { High degree of anaerobic germination potential } \\
\text { suitable for direct sowing }\end{array}$ & 43 \\
\hline & Kalajeera, Machhakanta and Haladichudi & $\begin{array}{l}\text { High level of tolerance to multiple stresses } \\
\text { (drought, salinity and flooding) }\end{array}$ & 40 \\
\hline & Kalajeera, Machhakanta and Haladichudi & $\begin{array}{l}\text { Superior leaf photosynthetic capacity, stomatal } \\
\text { traits, water-use and carboxylation efficiency }\end{array}$ & 11,41 \\
\hline \multirow[t]{2}{*}{ Finger millet } & Jhana, Lala, Kurkuti, Ladu, Bhadi and Taya & $\begin{array}{l}\text { Superior leaf photosynthetic and stomatal traits, } \\
\text { water-use and carboxylation efficiency and } \\
\text { shows adaptive mechanism to cope with } \\
\text { changing environment }\end{array}$ & 12,46 \\
\hline & Telenga mandia and Dasara mandia & $\begin{array}{l}\text { Most climate-resilient characters such as biotic } \\
\text { and abiotic stress tolerance, pest resistance } \\
\text { and low input requirement. }\end{array}$ & 45 \\
\hline
\end{tabular}

Dennst., Dioscorea oppositifolia L., D. pentaphylla L., D. pubera Blume. and D. wallichii Hook.f. ${ }^{35}$. Table 2 presents the nutritional properties of wild and cultivated yam tubers of Koraput. The proximate composition of wild yam tubers ranged from $3.82 \%$ to $5.42 \%$ ash, $1.55 \%$ to $1.90 \%$ fat, $1.45 \%$ to $1.60 \%$ fibre, $22.9 \%$ to $26.6 \%$ carbohydrate, $9.5 \%$ to $10.2 \%$ protein, and 148 to $163 \mathrm{kcal}$ gross energy in comparison to the cultivated species $(D$. alata), i.e. $3.16 \%$ ash, $0.91 \%$ fat, $1.40 \%$ fibre, $24.07 \%$ carbohydrate, $8.78 \%$ protein and $139 \mathrm{kcal}$ gross energy (Table 2). Wild yam tubers such as D. pubera, D. hamiltonii and D. oppositifolia showed superior mineral and nutritional contents than cultivated yam ${ }^{35}$. The micronutrient composition ranged from 60.33 to $89.4 \mathrm{mg} / 100 \mathrm{~g}$ of sodium, and 1029 to $1248 \mathrm{mg} / 100 \mathrm{~g}$ of potassium compared to $55.06 \mathrm{mg} / 100 \mathrm{~g}$ of sodium and $989 \mathrm{mg} / 100 \mathrm{~g}$ potassium in the cultivated species ${ }^{35}$. Padhan et al. ${ }^{36}$ studied the tuber quality and safety concerns about wild yam tubers, and reported that majority of these tubers are superior in essential minerals like calcium $(18.08-74.79 \mathrm{mg} /$ $100 \mathrm{~g})$, iron (11.15-74.79 mg/100 g), zinc (2.11-6.21 mg/ $100 \mathrm{~g}$ ) and phosphorus (179-248 mg/100 g). The level of antinutrients such as diosgenin, phytate and oxalate in raw tuber was significantly higher in wild than cultivated tubers $^{36}$. However, it was also reported that the antinutrient level was lower than that recommended by World Health Organization $^{36}$. The wild yam tubers have 2.19 $9.62 \mathrm{mg}$ phenol, $0.62-0.85 \mathrm{mg}$ flavonoid and $1.63-5.59 \%$ antioxidant capacity with higher free radical scavenging activity. They possess superior antioxidant capacity and can be a natural source of antioxidants ${ }^{37,38}$.

\section{Underutilized crop species for climate resilience}

Table 3 shows the list of underutilized wild crop species of Koraput for climate resilience and their useful agronomic traits. Mishra et al. ${ }^{29}$ identified six local rice landraces, viz. Haladichudi, Machhakanta, Kalajira, Mugudi, Pandakagura and Dangarbayagundar with high level of tolerance to drought stress by laboratory screening. On the basis of physiological introspection, three landraces (Haldichudi, Kalajeera and Machhakanta) showed superior photosynthesis and maintenance of higher water-use efficiency under drought condition than the tolerant check variety N22 (ref. 39). This result supplemented with molecular characterization based on drought tolerance QTL-linked SSR markers revealed that these landraces are more diverse, and the presence of one or more drought-tolerance-linked QTL. In addition to drought tolerance, these landraces showed higher degree of tolerance to multiple stresses like salinity and flooding stress $^{40}$. The grain yield of Kalajeera (22-25 q/ha), Machhakanta (25-30 q/ha) and Haladichudi (18-20 q/ha) was less than that of modern high-yielding varieties IR 42 (65-67 q/ha) and IR 64 (58-61 q/ha). The stomatal triats such as stomatal density and stomatal index of these landraces were superior compared to the high-yielding hybrid varieties (Table 4). They show higher resilience to the prevailing environment because of efficient gas exchange and stomatal traits ${ }^{11,41}$. After a rapid flooding tolerance screening of more than 88 lowland rice landraces from Koraput region, Basnamundi, Gadaba, Dokarakuji, Samudrabali and Surudaka were identified as the flooding-tolerant varieties of the region ${ }^{42}$. Moreover, three landraces, namely Basnamundi, Gadaba and Samudrabali showed better survival rates (97-98\%) than international flooding-tolerant check variety FR13A (95\%; Table 3). For lowland rice-growing areas affected by long-term flooding, these landraces are suitable for cultivation because for their better survival and elongation under water $^{43}$. It has also been revealed by molecular genotyping studies that these landraces contain flooding tolerance 
Table 4. Yield and climate-resilient traits of traditional rice and millets from Koraput over modern, high-yielding variety

\begin{tabular}{|c|c|c|c|c|c|c|c|}
\hline Variety & $\begin{array}{l}\text { Yield } \\
(\mathrm{q} / \mathrm{ha})\end{array}$ & $\begin{array}{c}\text { Photosynthetic } \\
\text { rate }(\mu \mathrm{mol} \\
\left.\mathrm{CO}_{2} \mathrm{~m}^{-2} \mathrm{~s}^{-1}\right)\end{array}$ & $\begin{array}{c}\text { Stomatal } \\
\text { conductance } \\
\left(\mathrm{mMol} \mathrm{H}_{2} \mathrm{O}\right. \\
\left.\mathrm{m}^{-2} \mathrm{~s}^{-1}\right)\end{array}$ & $\begin{array}{l}\text { Water-use } \\
\text { efficiency }\end{array}$ & $\begin{array}{c}\text { Carboxylation } \\
\text { efficiency }\end{array}$ & $\begin{array}{c}\text { Stomata } \\
\text { density } \\
\left(\text { no. } \mathrm{mm}^{-2}\right)\end{array}$ & $\begin{array}{l}\text { Stomatal } \\
\text { index }\end{array}$ \\
\hline \multicolumn{8}{|l|}{ Rice* } \\
\hline Kalajeera (Landraces of Koraput) & $22-25$ & $17.55 \pm 1.6$ & $91.7 \pm 4.06$ & $4.91 \pm 0.19$ & $0.065 \pm 0.003$ & $347.64 \pm 20.8$ & $7.76 \pm 0.36$ \\
\hline Haldichudi (Landraces of Koraput) & $18-20$ & $17.37 \pm 0.5$ & $88.1 \pm 4.25$ & $5.12 \pm 0.10$ & $0.063 \pm 0.008$ & $318.82 \pm 20.8$ & $6.02 \pm 0.20$ \\
\hline Machakanta (Landraces of Koraput) & $25-30$ & $17.51 \pm 1.0$ & $89.2 \pm 7.43$ & $5.38 \pm 0.11$ & $0.066 \pm 0.001$ & $323.52 \pm 21.5$ & $5.81 \pm 0.61$ \\
\hline IR 64 (hybrid variety) & $58-61$ & $14.85 \pm 0.4$ & $83.1 \pm 1.90$ & $4.18 \pm 0.22$ & $0.052 \pm 0.003$ & $264.70 \pm 11.5$ & $4.35 \pm 0.33$ \\
\hline IR 42 (hybrid variety) & $65-67$ & $15.02 \pm 1.0$ & $82.4 \pm 1.34$ & $4.62 \pm 0.16$ & $0.054 \pm 0.007$ & $294.11 \pm 21.5$ & $4.37 \pm 0.21$ \\
\hline \multicolumn{8}{|l|}{ Finger millet** } \\
\hline Jhana (Landraces of Koraput) & 18.0 & $19.18 \pm 0.19$ & $77.64 \pm 1.52$ & $4.96 \pm 0.14$ & $0.14 \pm 0.003$ & $43.74 \pm 3.83$ & $30.30 \pm 1.28$ \\
\hline Lala (Landraces of Koraput) & 16.0 & $15.42 \pm 0.12$ & $57.07 \pm 1.70$ & $4.68 \pm 0.01$ & $0.10 \pm 0.003$ & $43.74 \pm 3.83$ & $29.29 \pm 1.01$ \\
\hline Kurkuti (Landraces of Koraput) & 21.2 & $10.43 \pm 0.14$ & $52.21 \pm 1.21$ & $3.96 \pm 0.16$ & $0.08 \pm 0.002$ & $43.74 \pm 3.83$ & $23.30 \pm 0.31$ \\
\hline Ladu (Landraces of Koraput) & 17.2 & $11.63 \pm 0.18$ & $52.95 \pm 1.42$ & $3.55 \pm 0.23$ & $0.08 \pm 0.005$ & $31.24 \pm 3.83$ & $23.14 \pm 1.60$ \\
\hline Taya (Landraces of Koraput) & 20.5 & $17.61 \pm 0.93$ & $39.69 \pm 1.41$ & $5.86 \pm 0.32$ & $0.08 \pm 0.01$ & $43.74 \pm 3.83$ & $27.92 \pm 0.91$ \\
\hline Bhairabi (high yielding variety) & 27.5 & $13.99 \pm 0.67$ & $43.52 \pm 0.62$ & $3.60 \pm 0.24$ & $0.07 \pm 0.005$ & $38.74 \pm 1.76$ & $22.79 \pm 2.52$ \\
\hline
\end{tabular}

*Panda et al. ${ }^{11}$; **Panda et al. $^{41}$.

gene Sub 1 as in FR13A. Along with the flooding tolerance, three rice landraces (Basantichudi, Bausaganthi and Patadhan) have been identified as having superior anaerobic germination potential ${ }^{44}$. These landraces are associated with efficient carbohydrate management and coleoptile elongation than the tolerant check variety. Despite their poor phenotypes, these traditional landraces are identified as potential genetic resources for climateresilient breeding programmes and can be popularized globally.

Telugu mandia and Dasara mandia have been identified as the best climate-resilient millet varieties of this region ${ }^{45}$. Panda et al. $^{46}$ collected different local fingermillet genotypes from Koraput to evaluate their genetic diversity and study variability in morphological traits among them. The findings indicate that in spite of less productivity, these varieties show better agronomic traits and resistance to biotic and abiotic stresses. Some local finger-millet genotypes such as Kurkuti, Lala, Ladu, Jhana and Taya showed superior photosynthetic capacity, water-use efficiency and carboxylation efficiency compared to the other genotypes (Table 4). They also showed better stomatal density and stomatal index, and exhibited better coping mechanism with changing environment ${ }^{46}$. To popularize millet production in Koraput region, Pradhan et $a l^{12}$ studied the pattern of crop productivity, labour requirement and profitability along with nutrition awareness initiatives among the tribal communities. They have suggested better agro-management practices that improve millet production and are suitable for climatesmart agriculture.

Koraput farmers reported that during the cyclone Hudhdud in October 2014, most of the paddy and millet fields were affected and the plants were blown down due to heavy winds, but some of the traditional landraces of rice and millets could survive the fury of the cyclone ${ }^{47}$.
Choudhury $^{48}$ also reported that native rice varieties of Koraput such as Kolamali and Kaberigandha survived better than the modern varieties during the cyclones Philine and Hudhud that hit the Odisha coast in 2013 and 2014 respectively. The complete loss of paddy crops during the supercyclone in Odisha in October 1999 resulted in loss of confidence in high-yielding varieties among farmers, forcing them to switch back to traditional varieties which gave $30-40 \%$ higher yield ${ }^{49}$. In Koraput, climate variables such as temperature and rainfall have been studied from 1980 to 2016 by Panda et al. ${ }^{50}$. They noted that climate variations and loss of monsoon rainfall have a significant negative impact on crop yield. Under climate variable conditions, traditional landraces of rice and millets showed more adaptive responses and gave better yield. Thus, these traditional landraces are potential genetic resources for climate-resilient breeding programmes.

\section{Conclusion}

It is evident from the present study that tribal communities of Koraput largely cultivate and depend on traditional and wild crop resources for their food and livelihood. The superior indigenous gene pool of rice and millets identified should be popularized for climate-resilient breeding programmes. For alleviating hunger and malnutrition, the less familiar wild plants such as wild fruits, leaves and yam are a good alternative source of food. Necessary steps should be taken for mass consumption, domestication and to conserve these valuable wild crop resources in their natural habitat. A strategy to promote commercial production of these indigenous rice, millet and wild yam plants is required to boost the local economy by initiating processing, value addition and creating a market so as to 
reach more consumers. Above all, we must create mass awareness on the importance of wild and neglected crop resources of Koraput and their conservation for a sustainable future.

Conflict of interest: The authors reported that they have no conflict of interest.

1. IPCC, Impacts, adaptation and vulnerability, The Intergovernmental Panel on Climate Change, Fourth Assessment Report, Cambridge University Press, Cambridge, 2007.

2. Krishnamurthy, P. K., Lewis, K. and Choularton, R. J., Climate impacts on food security and nutrition: a review of existing knowledge. Met Office and WFP's Office for Climate Change, Environment and Disaster Risk Reduction, Exeter Devon, UK, 2012 .

3. Beddington, J., Food security: contributions from science to a new and greener revolution. Philos. Trans. R. Soc. London, Ser. B, 2010, 365, 61-71.

4. Singh, B., Bahuguna, A. and Bhatt, A., Small millets of Uttarakhand for sustainable nutritional security and biodiversity conservation. Int. J. Manage. Soc. Sci. Res., 2015, 4(8), 26-30.

5. Willett, W. et al., Food in the Anthropocene: the EAT-Lancet commission on healthy diets from sustainable food systems. Lancet, 2019, 393, 447-492.

6. Baldermann, S. et al., Are neglected plants the food for the future? Crit. Rev. Plant Sci., 2016, 35(2), 106-119.

7. FAO, IFAD, UNICEF, WFP and WHO, The state of food security and nutrition in the world 2018: building climate resilience for food security and nutrition, FAO, Rome, Italy, 2018.

8. Reardon, T. and Timmer, C. P., Five inter-linked transformations in the Asian agri-food economy: food security implications. Global Food Secur., 2014, 3(2), 108-117.

9. Swaminathan, M. S. and Kesavan, P. C., Agricultural research in an era of climate change. Agric. Res., 2012, 1(1), 3-11.

10. Cheeseman, J., Food security in the face of salinity, drought, climate change, and population growth. In Halophytes for Food Security in Dry Dands (eds Khan, M. A. et al.), Academic Press, San Diego, CA, USA, 2016, pp. 111-123.

11. Panda, D., Mahakud, A., Mohanty, B., Mishra, S. S. and Barik, J., Genotypic variation of photosynthetic gas exchange and stomatal traits in some traditional rice (Oryza sativa L.) landraces from Koraput, India for crop improvement. Physiol. Mol. Biol. Plants, 2018, 12(5), 973-983.

12. Pradhan, A., Panda, A. K. and Bhavani, R. V., Finger millet in tribal farming systems contributes to increased availability of nutritious food at household level: insights from India. Agric. Res., 2019, 8(4), 540-547.

13. Kumar, N. A., Nambi, V. A., Geetha Rani, M., Israel Oliver King, E. D., Chaudhury, S. S. and Mishra, S., Community agro-biodiversity conservation continuum: an integrated approach to achieve food and nutrition security. Curr. Sci., 2015, 109(3), 474-487.

14. Mabhaudhi, T., Chimonyo, V. G. P., Hlahla, S., Massawe, F., Mayes, S., Nhamo, L. and Modi, A. T., Prospects of orphan crops in climate change. Planta, 2019, 250, 695-708.

15. Dawson, I., Guarino, L. and Jaenicke, H., Underutilised plant species: impacts of promotion on biodiversity. The International Centre for Underutilised Crops Position Paper 23, ISBN: 978-9551560-05-9.

16. Mahapatra, A. K. and Panda, P. C., Wild edible fruit diversity and its significance in the livelihood of indigenous tribals: evidence from eastern India. Food Secur., 2012, 4(2), 219-234.

17. Hunter, D. et al., The potential of neglected and underutilized species for improving diets and nutrition. Planta, 2019, 250, 709719.
18. Mishra, S., Chaudhury, S. S. and Nambi, V. A., Strengthening of traditional seed selection practices with improved knowledge and skills of tribal farm families in Koraput District. Indian J. Tradit. Knowl., 2012, 11(3), 461-470.

19. Mishra, S. and Chaudhury, S. S., Ethno-botanical flora used by four major tribes of Koraput, Odisha, India. Genet. Resour. Crop Evol., 2012, 59(5), 793-804

20. Nayar, M. P., Singh, A. K. and Nair, K. N., Agrobiodiversity hotspots in India. Conservation and Benefit Sharing, Vol. 2, Protection of Plant Varieties \& Farmers' Rights Authority, New Delhi, 2009, p. 217.

21. Kar, G., James, B. K., Singh, R. and Mahapatra, I. C., Agroclimate and extreme weather analysis for successful crop production in Orissa. Research Bulletin 22, Water Technology Centre for Eastern Region, Bhubaneswar, 2020.

22. Mishra, S., Farming system in Jeypore tract of Orissa, India. Asian Agric. Hist., 2009, 13(4), 271-292.

23. Padhan, B. and Panda, D., Wild edible plant diversity and its ethno-medicinal use by indigenous tribes of Koraput, Odisha, India. Res. J. Agric. For. Sci., 2015, 3(9), 1-10.

24. Ramiah, K. and Ghose, R. L. M., Origin and distribution of cultivated plants of south Asia - rice. Indian J. Genet., 1951, 11, $7-13$.

25. Tripathy, S., Gurung, P. and Sharma, S. D., Intellectual property contributions with regard to rice genetic resources by tribes of south Orissa, India. Plant Genet. Resour. Newsl., 2005, 141, 7073.

26. Arunachalam, V., Chaudhury, S. S., Sarangi, S. K., Ray, T., Mohanty, B. P., Nambi, V. A. and Mishra, S., Rising on rice: the story of Jeypore. M.S. Swaminathan Research Foundation, Chennai, 2006, vol. 1, 39.

27. Roy, P. S., Patnaik, A., Rao, G. J. N., Patnaik, S. S. C., Chaudhury, S. S. and Sharma, S. G., Participatory and molecular marker assisted pure line selection for refinement of three premium rice landraces of Koraput, India. Agroecol. Sustain Food, 2016, 41(2), $167-185$.

28. Patra, B. C. and Dhua, S. R., Agro-morphological diversity scenario in upland rice germplasm of Jeypore tract. Genet. Resour. Crop Evol., 2003, 50(8), 825-828.

29. Mishra, S. S., Behera, P. K. and Panda, D., Genotypic variability for drought tolerance-related morpho-physiological traits among indigenous rice landraces of Jeypore tract of Odisha, India. $J$. Crop Imrpov., 2019, 33, 254-278.

30. Behera, P. K. and Panda, D., Genotypic variations of seed characteristics in indigenous aromatic rice landraces of Koraput, India. In National Conference on Emerging Trends in Plant Science Research, Ravenshaw University, Cuttack, 2020, p. 47.

31. Edwina, P. et al., Biochemical and antioxidant activities of pigmented landraces of Oryza sativa - Koraput District, Odisha, India. Int. Food Res., J., 2014, 21(5), 1941-1949.

32. Maganti, S., Swaminathan, R. and Parida, A., Variation in iron and zinc content in traditional rice genotypes. Agric. Res., 2019; https://doi.org/10.1007/s40003-019-00429-3.

33. Panda, D., Sailaja, N. H., Padhan, B. and Lenka, K., Sproutingassociated changes in nutritional and physico-functional properties of indigenous millets from Koraput, India. Proc. Natl. Acad. Sci., India, Sect. B, 2020, 90, 79-86.

34. Misra, S., Ethnobotany and nutritional status of some edible plants of south Odisha, India. Int. J. Adv. Agric. Sci. Technol., 2018, 5(2), 21-32.

35. Padhan, B., Biswas, M. and Panda, D., Nutritional, anti-nutritional and physico-functional properties of wild edible yam (Dioscorea spp.) tubers from Koraput, India. Food Biosci., 2020, 34, 100527.

36. Padhan, B., Biswas, M., Dhal, N. K. and Panda, D., Evaluation of mineral bioavailability and heavy metal content in indigenous food plant wild yams (Dioscorea spp.) from Koraput, India. J. Food Sci. Technol., 2018, 55, 4681-4686. 
37. Padhan, B., Nayak, J. K. and Panda, D., Natural antioxidant potential of selected underutilized wild yams (Dioscorea spp.) for health benefit. J. Food Sci. Technol., 2020, 57, 2370-2376.

38. Panda, D., Biswas, M. and Padhan, B., Traditional processing associated changes in chemical parameters of wild yam tubers from Koraput, Odisha, India. Indian J. Tradit. Knowl., 2020, 19(2), 266-276.

39. Mishra, S. S., Behera, P. K., Kumar, V., Lenka, S. K. and Panda, D., Physiological characterization and allelic diversity of selected drought tolerant traditional rice (Oryza sativa L.) landraces of Koraput, India. Physiol. Mol. Biol. Plants, 2018, 24(6), 10351046.

40. Panda, D., Mohanty, B., Behera, P. K., Barik, J. and Mishra, S. S., Harnessing leaf photosynthetic traits and antioxidant defence for multiple stress tolerance in three premium indigenous rice landraces of Jeypore tract of Odisha, India. Funct. Plant Biol., 2020, 47, 99-111.

41. Panda, D., Mishra, S. S., Mohanty, S. K., Behera, P. K. and Lenka, S. K., Data on genetic potentiality of folk rice (Oryza sativa L.) genotypes from Koraput, India in reference to drought tolerance traits. Data Brief, 2019, 25, 104363; https://doi.org/10.1016/ j.dib.2019.104363.

42. Barik, J., Kumar, V., Lenka, S. K. and Panda, D., An assessment of variation in morpho-physiological traits and genetic diversity in relation to submergence tolerance of five indigenous landraces of lowland rice. Rice Sci., 2020, 27(1), 32-43.

43. Barik, J., Kumar, V., Lenka, S. K. and Panda, D., Genetic potentiality of lowland indigenous indica rice (Oryza sativa L.) landraces to anaerobic germination potential. Plant Physiol. Rep., 2019, 24(2), 249-261.

44. Barik, J., Panda, D., Mohanthy, S. and Lenka, S. K., Leaf photosynthesis and antioxidant response in selected traditional rice landraces of Jeypore tract of Odisha, India to submergence. Physiol. Mol. Biol. Plants, 2019, 25(4), 847-863.

45. Mishra, C. S., Taraputia, T. and Suchen, B., Policy advocacy for climate smart agriculture in millets: an initiative for ensuring food security in tribal communities of Koraput tract, Odisha, India. Global Adv. Res. J. Agric. Sci., 2014, 3(7), 179-185.

46. Panda, D., Sailaja, N. H., Behera, P. K., Lenka, S. K. and Lenka, K., Genetic diversity of under-utilized indigenous finger millet genotypes from Koraput, India for crop improvement. J. Plant Biochem. Biotechnol., 2020; https://doi.org/10.1007/s13562-02000557-w.

47. Adhikari, P., Pragati-Koraput experiences with system of ragi intensification. Report from Koraput, PRAGATI, 2016; http://sri. cals.cornell.edu/countries/india/orissa/InOdisha_Pragati_SCI\%20_ Ragi14.pdf.

48. Choudhury, C., Guardians of the grains. The Hindu, 23 September 2017.

49. Dar, M. H. et al., Transforming rice cultivation in flood prone coastal Odisha to ensure food and economic security. Food Secur., 2017, 9, 711-722.

50. Panda, A. et al., Impact of climate variability on crop yield in Kalahandi, Bolangir, and Koraput districts of Odisha, India. Climate, 2019, 7, 126; doi:10.3390/cli7110126.

ACKNOWLEDGEMENT. We thank the tribal informants from Koraput district for sharing their valuable knowledge.

Received 20 April 2020; revised accepted 18 November 2020

doi: $10.18520 / \mathrm{cs} / \mathrm{v} 120 / \mathrm{i} 6 / 989-996$ 